\title{
The Earldoms under Edward I
}

Author(s): T. F. Tout

Source: Transactions of the Royal Historical Society, New Series, Vol. 8 (1894), pp. 129-155

Published by: Cambridge University Press on behalf of the Royal Historical Society Stable URL: http://www.jstor.org/stable/3678037

Accessed: 26-06-2016 08:57 UTC

Your use of the JSTOR archive indicates your acceptance of the Terms \& Conditions of Use, available at

http://about.jstor.org/terms

JSTOR is a not-for-profit service that helps scholars, researchers, and students discover, use, and build upon a wide range of content in a trusted digital archive. We use information technology and tools to increase productivity and facilitate new forms of scholarship. For more information about JSTOR, please contact support@jstor.org.

Cambridge University Press, Royal Historical Society are collaborating with JSTOR to digitize, preserve and extend access to Transactions of the Royal Historical Society 


\title{
THE EARLDOMS UNDER EDWARD I.
}

\author{
By Professor T. F. TOUT, M.A.
}

I Do not propose to lay before you to-night any new theory of the constitutional position of the earldoms under Edward I. My purpose is political rather than constitutional, and, where it is not political, biographical and topographical. I wish to attempt the task of describing simply and clearly what were the number and nature of the earldoms under Edward I., with what great houses they were connected, in what districts their strength mostly lay, what manner of men the earls themselves were, and in what relations they stood to the king. I fear that I have no novelty to bring forward. The details that I shall use will come nearly all from very obvious sources, such as the printed Calendars of Post Mortem Inquests, Dugdale's 'Baronage,' the Lords' 'Reports on the dignity of a Peer,' and the ordinary chronicles and printed records of the time. Many of my facts I came across in a task that has occupied me a good deal lately, and which I have found to be by no means an easy one. I have been trying to construct a territorial map of England under Edward I., with the special view of finding out in what districts lay the power of the chief baronial houses. My excuse for laying my facts before you is that, however trite and dull they may seem, they are not always known by those who might be expected to know them. When lecturers and text-book writers-to say nothing of more serious authors - are still sometimes content to repeat the grossest inaccuracies as to the power and position of the greater nobles - when the standard historical atlas makes the 'Grafschaft Oxford' the 'Gebiet der Vere,' and the N.S.-VOL. VIII. 
'Grafschaft Westmoreland' the 'Gebiet der Nevill,' the elementary truths that I wish to drive home cannot be said to have obtained very general acceptance. We may go so far in gratifying what a brilliant French scholar describes as the 'gout excessif de l'inédit ' that we are prone to forget how large a portion of historical truth is already in some form accessible to the earnest worker. It is truth of this old-fashioned sort that I wish to set before you to-night. So far as I shall have to generalise, all that I can hope to do is to point out the general bearing of the particular details on the broad currents of English history of the time, and see in particular what light our facts will throw on the character and policy of Edward I., and what phases of the chronic struggle of crown and baronage are best illustrated by his reign.

The reign of Edward I. is more generally looked upon as the starting-point of a new period than as the concluding act of an old one. And yet it is quite as true to regard the work of the most conservative of our great reforming kings as summing up the tendencies of preceding generations, as it is to look on it in its more usual aspect as the time which witnessed the laying of the foundations of the English constitution and of the English nation, such as we have known them in subsequent ages. The history of the great noble houses and of the estate of the baronage under Edward I. illustrates very clearly both these aspects of his policy. It was Edward-as we have often been told - who created the House of Lords, who defined the limited peerage of England, and saved us from the danger both of a small aristocratic oligarchy and of the infinitely extended privileged noblesse of most continental countries. Edward's reign is therefore a fresh starting-point in the history of the English peerage. Yet to contemporaries, ignorant of the future, his reign seemed rather the end of the old than the beginning of a new period. The dying out of great houses was one of the most conspicuous marks of the time, and the king's strong hand seldom unlocked the fountain of honour from which new titles and dignities flowed. The destruction of ancient houses was particularly conspicuous in the case of the earldoms, and Edward, faithful to the policy 
which had prevailed with the English monarchs since the accession of Henry II., took hardly any steps to supply the void by fresh creations. The idea of William the Conqueror to limit as far as possible the number of earldoms was still a guiding principle with his successors. The earldoms, though now shorn of most of their official position, and often standing in but a nominal relation to the shires which gave titles to their holders, still retained all the prestige which belonged to them as the highest rank of the peerage. Their holders were the natural leaders of the people-the hereditary advisers of the crown. Vast estates and a long tradition of authority still further heightened the position of the typical earl. Even in the hands of a dull and commonplace person-provided that he were but brave and strenuous - the dignity of earl was so great that it could not but exercise immense weight.

The number and dignity of the great earls had been steadily on the decline throughout the reign of Henry III. The last Mandeville Earl of Essex had died in 1237. In that same year the last of the old line of the Earls of Chester died at the age of thirty. When Hubert de Burgh died, 'full of years,' in I 243, his Earldom of Kent came to an end. The last Marshall Earl of Pembroke died in I245. In 1250 the last of the Longsword Earls of Salisbury died in Egypt. The earldom of Albemarle became practically extinct when the death of William de Fors in I260 was soon followed by that of his infant son. Two years later Earl William's brother-in-law, Baldwin of Redvers, the last Earl of Devon of that house, died at Paris, and only the Countess Isabella, sister of Baldwin, widow of Thomas, represented with her little daughter Avelina two illustrious baronial stocks. The Winchester earldom passed away in 1264, on the decease of Roger de Quincy. The earldoms of Leicester and Derby were transferred from the houses of Montfort and Ferrers to the crown as the two greatest forfeitures that attended the royalist triumph at the end of the Barons' Wars. Against such wholesale fallings away, it was but of little avail that some of the escheated earldoms were regranted to kinsfolk or dependents 
of the crown, that some were incorporated with other earldoms, that in one or two cases (for example, the earldom of Lancaster) fresh earldoms were, contrary to the general policy of the crown, called into existence, and that in other cases (the most conspicuous were the Fitzalan earldom of Arundel and the earldom of Cornwall revived in favour of Henry III.'s younger brother Richard, afterwards King of the Romans) old earldoms were revived for the benefit of new families. The result was a grievous diminution in the number of earldoms, which under Edward I. never exceeded tweive, a number that was still further diminished to ten before the end of his reign. Under Edward II. the number fell still lower. The chroniclers saw and lamented the falling off in the numbers of the earldoms. The anonymous chronicler of Edward II., who is generally described without much evidence as the Monk of Malmesbury, sets down the weakness of England which led to the crushing disaster of Bannockburn as largely due to the diminution of the number of the great earldoms. 'Posterity will wonder,' he says, ' how the Scots were audacious enough to resist the English, and why the valour of the English was suddenly found wanting. But a people without a leader is easily dispersed, and the members are found wanting when the head is laid low. There was a time when fifteen earls or more were wont to follow the standard of the English kings to battle. But now only five or six earls bear help to our king.' The Malmesbury writer can only see in this falling away the judgment of heaven on the pride and insolence of the English. Every man strives to surpass his betters, and those who have not sufficient patrimony turn to robbery and despoil their neighbours. 'Thus it is,' he continues, 'that the magnates of the land either fall in battle or die leaving no sons, or leave but daughters to divide their inheritance, so that the name of the father vanishes for ever.' The process of decay still went on; the few unlucky creations of Edward II. did little towards turning the tide. It was reserved for Edward III. to make a new starting-point in the

\footnotetext{
1 Chron. Edward I. and II, ed. Stubbs, II. 212 ; cf. II. 207.
} 
history of the English Earldoms by his lavish new creations. In I 328 three earls were appointed at once. ${ }^{1}$ In 1337 no less than seven earls were nominated together in Parliament. ${ }^{2}$ But Edward III.'s House of Lords carries us far beyond the limits of this paper. With the increase that followed his new creations something at least of the ancient prestige of the earldom departed for ever. Newfangled titles like duke and marquis had robbed the earl of the pride of place which had so long belonged to his office.

The process of diminution was checked during the greater part of Edward I.'s reign, though only to begin again with greater rapidity than ever under his successor. The Barons' Wars made almost a clean sweep of the older generation of actors in the political drama, and when Edward I. returned home in I274 to take upon himself the work of ruling England, he found that the majority of the eleven earls, who now alone held that office, were young and vigorous men, who were substantially his contemporaries. In I274 Edward was thirty-five years of age. His brother Edmund, Earl of Lancaster, Leicester, and Derby, was twenty-nine-six years his junior. His cousin Edmund Earl of Cornwall, who had succeeded his father Richard King of the Romans in 1272, was only twenty-four. Gilbert of Clare, Earl of Gloucester, who, like Edward, had begun his political career in the Barons' Wars, was thirty-one. The old Earl of Hereford was at death's door, and had long given place in all practical business to his son Humphrey de Bohun junior, a young man of twenty-three, who next year (1275) succeeded to' his father's title. Henry of Lacy, Earl of Lincoln and Salisbury, was about four or five and twenty. Roger Bigod, Earl of Norfolk, was thirty-four, a year younger than the king. Robert de Vere, Earl of Oxford, was about the same age. William of Valence, Earl of Pembroke, was a good deal older. I am not sure of the time of his birth, but he was probably approaching the ripe old age of fifty. John of

${ }^{1}$ Galfridus le Baker, p. 42, ed. Thompson. Murimuth, p. 58, R.S.

2 Murimuth, p. 29. 
Brittany, Earl of Richmond, Edward's brother-in-law, was exactly the king's age. John Warenne, Earl of Surrey, was four years older. William Beauchamp, Earl of Warwick, was about forty-seven, and twelve years Edward's senior. This makes (if we exclude the moribund Earl of Hereford) an average of a little over thirty-three years of age for the eleven earls.

The fact that a series of young earls started on their political career along with the young king is of the more significance when we remember that the early training of Edward had been almost exactly that of any other great English noble. Some of the earls had been Edward's comrades and companions from youth up, and the king was always a good friend. Moreover, many of them were Edward's near kinsfolk. Edmund of Lancaster was his brother; Edmund of Cornwall his first cousin; Gilbert of Gloucester was married to one of Edward's Poitevin cousins, and afterward became his son-in law; the young Humphrey of Hereford married in 1275 a cousin of Edward's wife; William of Valence was Edward's uncle; John of Brittany his brother-in-law. It was inevitable that so small a body of men, so closely united by ties of blood, education, and association, should either be warm friends or bitter enemies. When we remember the chronic hostility that was inevitable between a strong king and his great lords, it is not going too far to describe Edward and his earls as close friends. The baronial opposition hardly existed in the early part of his reign. Only the fierce and turbulent Gilbert of Gloucester kept up any consistent show of opposition. The earls, for the most part nearly related to Edward, were unswervingly faithful to him. Lancaster, Cornwall, Pembroke, and Richmond had no policy but that of their kinsman. And Henry of Lincoln, less closely connected by blood, was bound fast to Edward by ties of loyalty and service that endured as long as his life. Of all the earls, Henry of Lacy was the most persistent friend of Edward. With fidelity as great and ability much greater than either Edmund of Lancaster or Edmund of 
Cornwall, he remained the most steadfast and faithful of Edward's ministers.

Life in the middle ages was short and violent, and a certain lack of stamina often attended the greatest historical houses. But the long life and green old age of Edward showed that even in the thirteenth century, when men were thought old at five-and-forty, a healthy and active man might preserve his faculties unimpaired until he was seventy. And the same good health or good fortune attended the group of young earls who surrounded Edward's throne. It is next door to impossible to get any clear idea of the character of the subordinate characters of mediæval history. The chroniclers seldom go beyond vague epithets, and the legal records are of course silent as to motives. But we can faintly discern a sort of healthy monotony of character in Edward's earls. The majority of them shared in the king's strong health, sound physique, high courage, and vigorous character, though they had less claim to participate in his higher statesmanlike qualities. They were brave, strong, active, commonplace men, with the ordinary prejudices of their station.

For more than twenty years not a single earl died. The only change was that a new earl was added to their number. There were twelve English earls in 1294. The new comer was Richard Fitzalan, a young man born in 1267, who was now fully recognised as Earl of Arundel, though there seems no very definite evidence for Vincent's statement that he was created earl in 1289. The only other fresh creation had been the revival of the earldom of Chester (Edward's youthful appanage, on his accession annexed to the crown) in favour of the King's eldest son Alfonso, but the young prince's premature death soon brought the great palatinate back into the hands of his sorrowing father. The only difference was that the average age of the earls had risen to fifty-three, while Edward himself was now fifty-four. From the mediæval standpoint they were almost an assembly of patriarchs. Excluding Arundel, who was twenty-seven, the youngest earl was Hereford, who was thirty-nine; 
Pembroke and Warwick, the oldest, were between sixty and seventy.

The last few years of the thirteenth century sadly thinned the little circle. Edward had already lost his faithful wife Eleanor, and Bishop Burnell, the wisest of his ministers. In 1295 he lost the first of the noble band that had for three-and-twenty years given lustre to his throne. In that year died Gilbert of Gloucester, turbulent to the last, and hardly to be trusted by the king despite his marriage to Joan of Acre. In 1296 came more severe losses. Three earls perished during the year. Edmund of Lancaster died in Gascony, worn out by the trickery of the French and the burdens of defending his brother's Aquitanian inheritance. William of Pembroke perished at the good old age of sixtyfive, and Robert de Vere, the insignificant Earl of Oxford, was also gathered to his fathers at Castle Hedingham. Their successors were children, except Robert de Vere, the new Earl of Oxford, whose position was, however, as little important as that of his father. These deaths cut down the number of effective earls so considerably that men who had hitherto taken no great part in our history step of necessity into a foremost place. Edward's financial difficulties had brought about a renewal of the baronial opposition. As everybody knows, the Earls of Norfolk and Hereford became in 1297 the leaders of the opposition that secured the famous Confirmatio Cartarum. Dr. Stubbs has spoken with not too great severity of the factiousness of their conduct and the lowness of their ideals. It is worth pointing out that they simply led the barons, not by reason of any special fitness, but because there were no other full-blown earls who could take up the position. The Earls of Gloucester, Pembroke, and Lancaster were children; the Earl of Warwick an old man ; the Earl of Cornwall was the king's close friend and near kinsman; the Earl of Lincoln was Edward's most trusted minister; Richmond was Duke of Brittany-a non-resident foreigner; the Earl of Arundel was serving in Gascony; Warenne was regent of Scotland; the Earl of Oxford was 
young and poor. There are no earls left except Bohun and Bigod, who thus had greatness forced upon them because there was positively not a single other earl available to give dignity and splendour to the ranks of the opposition.

The circle of Edward's old earls was now still further narrowed. In I 298 Hereford himself died, as did William Beauchamp, the venerable Earl of Warwick. In I300 Edmund of Cornwall followed them to the grave. Arundel died in I 302, Surrey in 1 305, and John of Dreux (Earl of Richmond and Duke of Brittany) and Roger of Norfolk in 1306. Of the eleven earls who had welcomed Edward when he first took possession of the government of England, one only survived him. This was the faithful Henry of Lincoln, who did not die till I I I I, striving down to the end of his life to devote to the thankless service of Edward II. the loyalty and faithfulness that he had so long lavished upon Edward I.

Much need not be said of the younger generation of earls who during the last ten years of Edward's reign gradually took the places that their fathers had held so long in the king's court, host, and council. The earldoms of Arundel, Gloucester, and Surrey were held by minors, whose active career only began with the last campaign of Edward against the Scots. Edmund Fitzalan, Gilbert of Clare (Edward's grandson), and John of Warenne all received the grade of knighthood at that solemn Whitsuntide feast in I 306 when Edward's eldest surviving son, Edward of Carnarvon, was himself dubbed knight by his father. Edward of Carnarvon, it may be added, had himself been added to the number of the earls in 1302, when his father conferred on him the Principality of Wales and the earldom of Chester. It is true that during Gilbert of Clare's minority his stepfather, Ralph of Monthermer, held for a time the earldom in right of his wife, Joan of Acre. But though Edward I. might get over his indignation at his daughter's second marriage with a simple knight, neither the custody of the Gloucester inheritance, nor the writ of summons as an earl to Parliament, nor the favour of the sovereign and his 
daughter, nor even the rich provision (on paper, at least) which Edward made for his unwelcome son-in-law at the expense of the rebellious Scots, could give a Ralph of Monthermer-strenuous knight though he might be-the status of a magnate of the house of Clare. There is no need to say anything of the Earls of Angus and Buchan and other Scotch earls of Edward's party, who were rewarded for their faithful service, or consoled during their exile, by an occasional summons to the English Parliament.

A second group of the younger generation of earls comprised those who were considerably the seniors of these four contemporaries of the Prince of Wales, and were already in possession of their estates some years before the old king's death. Thomas of Lancaster, born perhaps in 1278 , had the livery of his father's three earldoms in 1298 , and became the husband of Alice de Lacy, the heiress of her father's earldoms of Lincoln and Salisbury, in I294. But it needed the stormy days of the weak Edward II. to bring out the true character of the violent, greedy, and incapable faction-leader, whose great possessions and strong passions made him the leader of the turbulent Ordainers in their long war against his cousin, and whose violent death at Pontefract made him, unworthy as he was, the martyr of the cause of popular liberty. The same may be said of the new Earl of Warwick, Guy de Beauchamp, the 'black dog of Arden,' as Gaveston styled him, the most implacable and treacherous of the enemies of the Gascon favourite. Warwick was twenty-eight years old when he succeeded to his father's earldom in 1298 , but he made no very great mark in the history of the later years of Edward I. In the same position was Aymer de Valence, the new Earl of Pembroke, born a little before I280, who began his active career with his first summons to Parliament in 1297. The young Earl Humphrey of Hereford was about four years older, but his marriage in 1302 to Edward's daughter Elizabeth, the widowed Countess of Holland, kept him for a time a supporter of the royal policy. Even more strenuous in the same policy was John of Brittany 
(Earl of Richmond after 1 306), who had long represented the interests of his father, the reigning Duke of Brittany, in England, and who was so thoroughly trusted by his uncle, Edward I., that he made him the chief representative of his policy in Scotland. Under Edward II. nearly all these earls figured among the Ordainers. Under Edward I. they preserved an extraordinary tranquillity.

The earldoms of Cornwall and Norfolk lapsed to the crown, as neither Edmund of Cornwall nor Roger Bigod left any children. John of London, the panegyrist of Edward, regards the acquisition of these two earldoms by the king as second only in importance to the conquests of Wales and Scotland. After speaking of these latter conquests he goes on: 'Nibilominus comitatibus Cornubiæ et Northfolchiæ, disponente Eo cujus est orbis terræ et plenitudo eius, ad manus Edwardi mirabiliter devolutis, suis successoribus, amplissimam reliquit materiam gloriandi.' ' But even before Roger Bigod's death Edward had got a tight hold of his succession. Worn out by the long struggle against the proud and relentless king, crippled with debt and unable to meet the demands of his brother-a clerk named John, who pressed him for repayment of loans advanced to him-Norfolk was forced in 1302 to accept the hard terms which Edward imposed upon him. He absolutely surrendered his estates and dignities to the king, who, after a short interval, granted them back to him under the limitations of the Statute de Donis, to be held by him and the heirs of his body. On Norfolk dying four years later, without children, the whole of his estates lapsed to the crown. They were destined by Edward to form the appanage of his son by his second wife, Thomas of Brotherton, then a boy of six, but it was not until the next reign that the regrant of the earldom was effected.

Edward I. had more than once already pursued the same policy which he carried off so successfully in the case of the Earl Marshal. Early in the reign he had procured from Isabella de Redvers, the heiress of the Devon earldom and

' Commendatio Lamentabilis, in Stubbs's Chron. E. I. and II., II. 9. 
the mother-in-law of Edmund of Lancaster, the reversion of her lordship of the Isle of Wight. After her death in I293 Edward became direct lord of the island, leaving only the Devonshire property to revert to Isabel's heirs, the Courtenays. Again in I3O2, on the occasion of bis marriage with the king's daughter Elizabeth, Humphrey of Hereford went through the same form of surrendering his estates to the crown and receiving them back entailed on the heirs of his body. But the large family which Elizabeth bore to Humphrey made in this case Edward's precaution of no practical importance. In such transactions we are reminded very strongly of the similar policy of Philip the Hardy, who, as M. Langlois points out, was never weary of rounding off the royal domain by various contracts and agreements with his vassals, and who, though, like Edward, professing to recognise every undoubted legal right of the feudations, took good care not to allow them any fresh claim, and strove by all the subtleties of mediæval chicane to hedge in and limit even those rights which they actually possessed.

Edward's policy to the earldoms now took a very definite shape. He sought wherever he could to absorb them gradually into the sphere of the royal influence. He strove to acquire for the royal family as many of the earldoms as he could, and thus to turn to the service of the crown resources which for many previous generations had been employed in keeping the crown in check. The actual escheats helped largely in this direction. The surrenders and regrants under conditions made a step still farther forward, but a series of judicious marriage alliances were the most effective means of absorbing decaying families into the royal house. Edward I. pursued, in fact, the policy of filling the great fiefs with members of the royal house and concentrating them in a few hands which Edward III. was afterwards to carry out more systematically in his famous family settlement.

Something had already been done in this direction before Edward's time. Edmund of Lancaster, no doubt largely through Edward's influence, had not only been endowed with 
the new earldom of Lancaster and the lapsed earldoms of Leicester and Derby. He had been married, as we have seen, to the greatest heiress of her time. If Avelina de Fors had lived she would have inherited both her mother's great possessions - the estates of the Devon earldom and the Isle of Wight, as well as the rich northern inheritance of the Earls of Albemarle and Holderness, which came to her from her father. But Avelina's death without children during her mother's lifetime robbed Edmund of this double prospect. A great inheritance came indeed to Edmund by his second wife, but the regency of Champagne and the prospects of the same position in Navarre did nothing to improve Edmund's position as a great English nobleman, though it made him for several years one of the great peers of France. But Edward found another great heiress for Edmund's eldest son, Thomas of Lancaster. This was Alice of Lacy, the sole heiress through her brothers' untimely deaths of the two earldoms, Lincoln and Salisbury, which were held by Henry de Lacy. After I 3 I I Earl Thomas of Lancaster ruled over no less than five earldoms.

Other marriages tended in the same direction. The marriage of Joan of Acre with Gilbert of Gloucester secured the succession of the Gloucester inheritance to Edward's grandson, the young Earl Gilbert, who died fighting so gallantly at Bannockburn. The marriage of the younger Humphrey de Bohun with Elizabeth of Holland secured for another grandson of Edward I. the earldom of Hereford. The earldom of Chester belonged to the king's eldest son. Cornwall, up to I 310 , was in the hands of his cousin, and afterwards escheated to the king. Add to these facts that many of the other earls-Pembroke, Richmond, and Warenne, for example-were already near kinsmen of the king, and we can measure the success of Edward's policy, a policy carried out more completely when his younger children, Edmund of Woodstock and Thomas of Brotherton, received from their eldest brother the earldoms of Kent and Norfolk. There is no need to expatiate on the failure of this policy. The 
royal earldoms thus strengthened by Edward's care, only strengthened the great combination against Edward II. which passed the ordinances and finally drove the king from the throne.

I must now turn to another side of my subject, and explain very briefly the territorial position of the various earldoms under Edward. This is a difficult task, partly because of the imperfection of our printed materials ${ }^{1}$ and partly because of the extraordinary way in which the estates of the great landholders were scattered in small parcels all over England. Despite the strong tendencies that made for concentration of estates, the famous policy of William the Conqueror still prevailed in spirit. We must seek for the honour of Wallingford almost everywhere besides in Berkshire, and the honour of Eye was by no means a great jurisdiction enclosed within a ring fence in Suffolk. Kidwelly was part of the earldom of Lancaster, and in a great part of Lancashire the earl who took his name from the shire had very little property. In what I am laying before you I shall ignore the small scattered estates, and speak only, and then but in very general terms, of the greater aggregation of territory, jurisdiction, and influence. I will take I290, as nearly as I can, as the period at which to make the description. It is before the great changes of the end of Edward's reign. It is late enough on to enable such changes as had been effected earlier to have worked out their results.

The greatest aggregations of territory belonged to the king's nearest kinsmen among the earls - the two Edmunds of Cornwall and Lancaster. The earldom of Edmund of Cornwall included not only a vast number of manors, possessions, and jurisdictions in the county of that name, along with the

1 The so-called calendar of Inquisitiones post Mortem of the Rec. Com. is the most tantalising and vexatious of authorities. We want the Post Mortem Inquests calendared with the same scholarship and skill as has been shown in the admirable Close and Patent Roll Calendars that are now emanating from Fetter Lane. I have not given references to the particular passages of the Calendar of Inquests, but nearly all the subsequent statements of fact are derived from this source. 
pleas of the shire, the profits of the stannaries, and a whole swarm of similar rights; the earldom also included a vast tract in Devonshire, the huge manor of Lidford, the whole of Dartmoor, and other lands extending as far as Exeter, which city with its castle was within the earl's domain. A prince who ruled from the Land's End to Exeter was a potentate of no small authority, and we can well understand the strong terms employed by the chroniclers when this great territory was added to the royal demesne in I300. But Edmund's possessions were much more extensive than these. He held a great estate in the Upper Thames valley, the nucleus of which were his honours of Wallingford and St. Valery. From his favourite abode in Wallingford Castle he ruled over nearly the whole of southern and south-eastern Oxfordshire, from Henley up to the higher reaches of the Cherwell valley. Moreover, he possessed the districts immediately around Wallingford, in Berkshire, a good slice of the vale of White Horse, with Didcot and Pusey, and a much greater extent of territory in Buckinghamshire, with Eton, Datchet, Amersham, and Swanbourne, with a considerable estate in the north of the county. These Buckinghamshire possessions were practically continuous with the great Hertfordshire estate that centred round the castle and honour of Berkhamstead, while more to the south they were prolonged into Middlesex, where the earl's possessions included Isleworth and Twickenham. This vast property of the middle Thames was almost as extensive and a great deal richer than the-remote western earldom. There was, however, a bridge between what Edmund held in the Thames valley and his western earldom in the shape of some scattered Dorsetshire, Wiltshire, and Gloucestershire estates, including the town of Chippenham and the castle of Mere. Edmund was also a great man in Western Suffolk, where he possessed the town, castle, and honour of Eye. Another great aggregation of Edmund's territory was in the north-west of the Midlands. In Lincolnshire his manors ran all along the east of the county from the banks of the Trent and Humber down to the region 
round Stamford, in which district his manors lay particularly thick upon the map. These possessions bordered on Rutland, where he possessed the castle and town of Oakham, the permanent sheriffdom of the little shire, a few manors, and many centres of revenue and jurisdiction. Further south he had Rockingham as the centre of his Northamptonshire property. His northernmost estate was in Yorkshire, where he owned the town and castle of Knaresborough, the towns of Boroughbridge and Aldborough, and an extensive property in the southern part of the North Riding. This long and tedious list is by no means exhaustive. In no part of central and southern England was his power quite unrepresented. It was a good thing for Edward that Edmund was a peaceloving and faithful subject. His shadowy and indistinct figure comes seldom across the history of the time, save when, during Edward's long absences abroad, he acted as regent for his cousin. He married a sister of Earl Gilbert of Gloucester, but died without issue.

Edmund of Lancaster is almost as shadowy a personage as Edmund of Cornwall, and, like his namesake, seems to have had no policy except the loyal fulfilment of his brother's wishes. Of him and his character, career, and estates I need say little, as you will before long be in a position to read an elaborate monograph on him in the 'English Historical Review' by a pupil of mine, Mr. W. E. Rhodes. What distinguishes him from the Earl of Cornwall was that he was a great man beyond sea as well as in England, by reason of his second marriage with Blanche of Artois, the granddaughter of the French king, herself the Queen Dowager of Navarre and Duchess of Champagne, and through his guardianship of his stepdaughter Joan, who became the wife of Philip the Fair of France, bringing to the French crown as her rich marriage portion that duchy of Champagne over which Edmund had ruled for several years as regent. But though thus called to great destinies, Edmund's character and ability were hardly equal to his position. He was brave, loyal, religious, chivalrous, and faithful ; he was open-handed 
and popular with soldiers, but he was easily outwitted as a diplomatist, and easily discouraged both in the Cabinet and in the field. His chief historical importance after all lies in his great possessions, in the means taken to enlarge them still farther, and in the fact that he was the ancestor of the famous line of earls and dukes of Lancaster, who, after a century of leadership of opposition and championship of constitutional government and ecclesiastical orthodoxy, at last mounted the throne in the person of Henry IV.

The three earldoms of Edmund of Lancaster, Leicester, and Derby had best be taken together, so as to get a general view of Edmund of Lancaster's territorial influence. His estates were even more widely scattered than those of Edmund of Cornwall. Perhaps the greatest seat of his power was in the northern and central midlands, but he was also a mighty man in the north (especially in Lancashire and Yorkshire), and in the southern marches of Wales. His chief centre of influence included the whole of eastern Derbyshire, the northern parts of Nottinghamshire, the east of Lincolnshire (Lindsey), nearly the whole of Leicestershire (where Leicester itself, one of the great boroughs of mediæval England, was included in his domain), the north-eastern parts of Staffordshire, including Newcastle-under-Lyme and the great fortress of Tutbury, while more to the south his power extended into Warwickshire, where he largely resided at Kenilworth, and some parts of Northamptonshire. In the whole Trent valley, from its source to the Isle of Axholme, he was the greatest lord. Moreover, his northern property was sufficiently near at hand not to stand quite out of relation to his central estates. In Lancashire he ruled supreme in his castie of Lancaster over the lands between the Ribble and the mountains of the Lake District, as well as in that south-western hundred whose name of West Derby suggested some sort of connection with his second earldom, and which included Liverpool and all the region around it. In Yorkshire his possessions were not so extensive as those of his successors, though he was master of Essingwold and Pickering, and of a fertile region to the N.S.-VOL. VIII. 
south of the great moorlands of the North Riding. He had an outlying estate in Northumberland round the sea-girt castle of Dunstanburgh, another in Suffolk, and, like most of the magnates of the time, a territory of no small extent in the southern marches of Wales, where he ruled like a little king, with very extensive franchises, over the castle and region of Kidwelly in what is now but was not then Carmarthenshire, and was equally powerful in an important stretch of rich and beautiful country between the Usk and the Wye, in what was then called Upper Gwent, and is now called northern Monmouthshire. Monmouth, town and castle, was the capital of this little marcher state; the honour of Monmouth also included the castles of Grosmont, Skenfrith, and Whitecastle. An important outlying piece of property was the estate in the Vale of Kennet in Southern Berkshire that centred round Hungerford.

Had Edmund had any children by Avelina de Fors he would have added to this vast estate the lordship of Wight and the property of the old Redvers earldom of Devon, which included the most fertile regions of the great western county. His second wife brought him influence abroad which in some way compensated for the loss of the prospective inheritance of Isabella of Redvers. The great marriage concluded for his son, the future Earl Thomas, added for a time to these possessions the inheritance of Henry de Lacy. It will be best, then, to deal next with the two earldoms of Lincoln and Salisbury, which Henry de Lacy handed on to the faithless husband of his daughter Alice.

The possessions of Henry de Lacy were admirably qualified to round off the inheritance of Edmund of Lancaster. Side by side with each great mass of Lancaster property, we find with curious regularity a large slice of the Lacy estates. Thus the one part of Lancashire where Edmund had no influence was the special field of the Lacy family. In the hundreds of Blackburn and Salford, the eastern and southeastern parts of the shire, Lacy ruled over Clitheroe, Colne, Burnley, Darwen, Bury, Rochdale, and Middleton, while, on the 
other side of the Pennine Chain, his estates extended down the river valleys of the West Riding, past his castle of Pontefract to the confluence of the Ouse and the Trent. This great block of territory just formed the segment of the irregular circle in which the lands of Lancaster extended, in a line following pretty closely the vast sweep of the Trent, and closely connected the Lancashire estates with the Derbyshire and Leicestershire property which had passed to Edmund from the Ferrars and the Montforts. In the same way a bit of Lacy territory ran like a wedge in north Nottinghamshire between Edmund's Derbyshire and Nottinghamshire lands, while a long stretch of Lacy manors along the course of the Witham connected the latter Lancaster estate with Edmund's lands in Lindsey. Lincoln itself belonged largely to its earl, as did the castle of Bolingbroke, which almost approached Edmund's territory. Castle Donington and a bit of Lacy territory in northern Leicestershire similarly connected Edmund's Derbyshire lands with his great possessions in Leicestershire, while even in remote Dorsetshire the Lacy property north of Wareham was quite contiguous to the scattered Wiltshire and Dorsetshire property of the house of Lancaster. In the Lancashire hundred of West Derby, the Lacys held Knowsley, Widnes, and, beyond the Mersey, the lordship and castle of Halton in the Cheshire palatinate. And the great seat of the Lacy power in the turbulent Welsh marches was not far removed. There Edward's love of his faithful servant had conferred on Earl Henry two of the Four Cantreds of the Plain Country (Perveddwlad) between the Cheshire boundary and the River Conway, which had been wrested finally from Llywelyn of Wales in 1277. These were the cantreds of Rhos and Rhuvoniog, and included within their limits the castle and town of Denbigh, henceforth the capital of the Lacy march in the fair and fertile vale of Clwyd, while the region of Kimmerch, also granted to Lacy, included the hill country south-west of the valley as far as the boundaries of Edward's own domain lands in the conquered Principality of Wales. Add to these some 
scattered Lacy estates in Herefordshire and the Gwent district that were close adjoining Edmund's lordship of Monmouth, and we see how remarkably the union of the houses of Lancaster and Lacy increased the territorial coherence of the heir of both. But the union was not very enduring. The adulterous passion of Earl Thomas for the wife of Earl Warenne led to a violent breach between him and Alice Lacy. Their union was moreover childless, and but few of the Lacy estates passed finally to Henry of Lancaster, the younger son and ultimate successor of Earl Edmund and the ancestor of the later earls and dukes of Lancaster.

Had we arranged the earldoms in their order of importance, the property of the great house of Clare would have been described immediately after the two great royal earldoms of Cornwall and Lancaster. And had we dealt with the earls in order of their personal character, there is none who could rightly be put before the strong, self-willed, vigorous and turbulent Gilbert the Red, in turns the saviour of Edward in the crisis of the Barons' War, his steadfast opponent when the victorious prince pressed too hardly on the defeated party of the Montforts, his close ally in breaking down the power of Llywelyn, his persistent foe in the constitutional difficulties in the earlier part of his reign, and, finally, the king's friend and son-in-law, though even in that capacity he did not hesitate to deeply offend his wife's father by his famous quarrel and private war with the Earl of Hereford. The power of Earl Gilbert of Gloucester centred in the west. He had outlying estates in North Devon, and in southern and eastern Dorset, wl ere Portland, Weymouth, Wareham, and Cranborne with its rhase acknowledged him as landlord. In Gloucestershire his property extended along the line of the Cotswolds from Thornoury and Chipping Sodbury to Chipping Campden, while it went down into the plain where Tewkesbury, whose great abbey contained the tombs of more than one line of Gloucester earls, stands at the confluence of the Avon and the Severn, and it extended eastwards into the upper Thames valley at Burford and Fairford. Even more important were 
the Clare lands beyond the Severn. Gilbert's vast property in South Wales made him the most powerful of the lords marchers. From his castle of Cardiff he ruled as freely over his palatinate of Glamorgan as Edward himself ruled over his palatinate of Chester. So important was the lordship of Glamorgan that it had in all respects the organisation of a county. Its court was a county court, its chief officer was a sheriff, and nothing but the fact that its lords were always earls by another title prevented it getting a name as dignified as the less important earldom of Pembroke further west. In this great territory Gilbert of Clare ruled like a despot over his Welsh and Norman vassals alike. The nimble Welshmen of the hills supplied him with as many light-armed infantry as he chose to levy, while the descendants of the companions of Fitzhamon gave him a heavy-armed train of knights and squires. It has been often pointed out how important to a great English earl was the Welsh marcher lordship, where he could levy troops and play the feudal prince in a way that the king's strong arm prevented him doing in England. And not even Robert of Gloucester, the founder of the earldom, nor Gilbert's brother Richard of Clare, the associate of Earl Simon in his early struggles, knew more fully how to play their part than Earl Gilbert the Red. His private wars distracted the whole west. The Welsh often felt his heavy hand, and his castle of Caerphilly, built in the last years of Henry III.'s reign, brought in a new type of stronghold that Edward was in after years glad to copy at Carnarvon and Beaumaris. No wonder Edward was delighted to have him for his son-in-law. It was, Edward hoped, a new pledge for the security of the throne that his grandson was the heir to the Gloucester and Glamorgan inheritance.

Earl Gilbert's Welsh lands went beyond the old Glamorganshire of Fitzhamon and Robert, son of Henry I. To the west it included Neath with its castle. To the north it took in most of the wild hill country that separated the vale of Glamorgan from the more northerly march of Brecon. To the east the Clare possessions in Netherwent, between the Usk 
and the Wye, included the towns of Caerleon and Usk and formed a sort of bridge leading into Gloucestershire. And in addition to these last Welsh western estates Earl Gilbert was also a great man in Ireland.' Moreover, the Clares were still strong in the cradle of their race in the extreme east. They had very little in Hertfordshire save the title of Earl of Hertford: but in Suffolk they had a respectable property round about the little town of Clare which either gave them their name or received its name from them. In the extreme north-west of Norfolk they ruled over the neighbourhood of Wells and Walsingham. And far more extensive and important than these districts was their great inheritance in Kent and Surrey, where a string of Clare manors ran along the upper Medway, past the famous Clare fortress of Tunbridge, westwards across the Surrey border; while on the north of the same county they were lords of Camberwell, within a very short distance of the capital itself. Even when the Clare power was on the wane, the scramble between the three husbands of the three sisters and heiresses of the Earl Gilbert that fought at Bannockburn did a great deal to pull down the throne of Edward II.

I must pass more briefly over the remaining earldoms. Richard Fitzalan, Earl of Arundel, had two great centres of influence. From his castle of Arundel he ruled over a large part of western Sussex, while his castles of Oswestry and Clun marked the two chief seats of his power in what was sometimes carelessly called even in those days western Shropshire; but which was more properly not included within that county until the reign of Henry VIII., being at this period half independent lordships marcher with extensive immunities, and no great danger from Welsh attack to lessen their practical value. Even more completely than the Clares, the Fitzalans

1 I have excluded the Irish estates of the various earls from my examination. Though like their Welsh lands they were useful as a recruiting ground of light irfantry and as a field for the exercise of feudal power, they cost more than they brought and were becoming more a source of weakness than of strength to their owners. Moreover, they stood in a much more remote relation to general English politics than their nearer and more accessible Welsh estates. 
were a marcher power, and the turbulent career and tragic fate of Earl Edmund of Arundel shows that he at least had no small share of the fierce marcher spirit. The Bohun Earls of Hereford and Essex belong to the same type. Their power, greater than the Fitzalans but less than that of the Clares, was mainly in the Welsh marches, though they also possessed a considerable territory in the richer and more settled regions of south-eastern England. Their Herefordshire estates were in the close neighbourhood of their marcher lordship of Brecon in the rich vale of Usk, a district much less than the modern Breconshire, yet big enough to constantly excite the jealousy of their southern neighbours, the Clares. Hence the famous quarrel of Earls Humphrey and Gilbert to which I have already alluded. In the other end of England, the Bohuns had a considerable property in southern Hertfordshire, northern Middlesex, and north-western Essex. Their estates ran as near London as Enfield, and included the chief Bohun residence, the castle of Pleshey in Essex. Kimbolton in Huntingdonshire was an outlying Bohun estate. With a position so analogous to that of the Clares, Edward thought he did a good stroke of business by marrying the younger Earl Humphrey to his daughter Elizabeth. Yet Humphrey died at Boroughbridge fighting hard for the cause of Thomas of Lancaster.

Like the Clares, Bohuns, and Fitzalans, John Earl Warenne had (if we may use the phrase) one foot in the east and another in the west. His nominal earldom was doubtless that of Surrey, where he was lord of Dorking and Reigate, but the more important part of his home estate stretched southwards from these two towns through central Sussex, passing Cuckfield and Lewes, and advancing straight to the south coast. Lewes Castle was his chief stronghold. Though mainly famous for his celebrated baring of the rusty sword when Edward's commissioners ventured to inquire by what warranty he held his jurisdictions, Earl John was in the main a strenuous supporter of Edward. He married one of Edward's Poitevin aunts; he fought manfully for the 
crown at Lewes, on a battlefield that was part of his own estate; he did good work against the Welsh; and he was regent, though a rather lazy and incompetent regent, of Scotland until the revolt of Wallace taught Edward that he must confide that great post to stronger hands. Earl John received a great accession of territory at the expense of the Welsh after the war of 1277. He was made lord of Bromfield and Yale, the parts of the modern south-east Denbighshire between the Flintshire border and the banks of the Dee, which he ruled over from his hill castle of Dinas Bran over against Llangollen. He also had a great estate in the West Riding of Yorkshire, running diagonally from northwest to south-east across the Yorkshire property of the Lacies. Sandall and Conisbrough Castles were the chief strongholds of the Warennes in Yorkshire. Halifax, Dewsbury, and Wakefield were among their possessions. They also had a fair estate in Kesteven, Lincolnshire, where they were lords of Grantham and Stamford. Their property both in Sussex and in the northern marches of Wales was immediately adjacent to the estates of the Fitzalans. Mediæval matchmakers thought more of rounding off contiguous properties than of romantic love, and the same motives which had led to the marriage of Thomas of Lancaster with Alice Lacy pleaded eloquently for the union of the Warennes and Fitzalans. Earl John's grandson, another Earl John, was the last Earl of Surrey of the house of Warenne. Alice, his sister and heiress, married Edmund Fitzalan, Earl of Arundel, after 1302. Their son, Richard Fitzalan, became ultimately Earl both of Surrey and Sussex.

Roger Bigod, Earl of Norfolk and Suffolk, had his chief property in the two counties from which he derived his titles. The Bohun manors were scattered far and wide over the two shires of East Anglia, but were nowhere more thick than round Earl Roger's castle of Bungay on the Waveney. We have seen how his earldom lapsed to the crown on his death in I302. The Earl of Warwick, William Beauchamp, held the town and castle of Warwick, but the mass of his property 
was in Worcestershire, including Worcester, Droitwich, and Elmley Castle, south of the Avon among the Bredon Hills, as chief seats of his influence.

The remaining three earls were not of the first importance. William of Valence, Earl of Pembroke, the only one of the whole Lusignan brood to get permanently settled in England, had acquired, through Henry III.'s good will and a lucky match with the heiress, the Welsh palatine earldom of Pembroke, that had such a great position under the earls of the house of Marshall, whose hereditary office had been transmitted, also through the female line, to the earls of Norfolk. But the Pembroke earldom of the Valences was hardly so important as that of the Marshalls. They were great men, of course, in South Wales, though their earldom corresponded still less in extent to the modern Pembrokeshire than the Glamorgan lordship of the Clares corresponded to the modern Glamorganshire. Speaking roughly, it only included the lands between the south bank, Milford Haven, and the sea. Haverfordwest belonged to Queen Eleanor. The north of the county, Dewsland, belonged to the bishops of St. David's, and there were independent lords of Roch, Walwyn's Castle and other small strongholds, though these, no doubt, tended to fall under the Pembroke influence. The other possessions of the Valences were not great, and widely scattered. They had some lands in the south-eastern extremity of the marches round their castle of Goodrich, near Ross. They had some lands in Norfolk, and some widely-scattered manors in Kent, of which the best known are Sutton Valence and Brabourne. In West Berkshire they were lords of Shrivenham. Their most important group of English land was in South-east Hertfordshire round their castle of Hertford.

The old connection of the earldom of Richmond with a foreign reigning house had rendered its history rather precarious and full of changes. Under Edward's brother-in-law and nephew this earldom became as influential as it ever was in English history. Its chief lands were in the district 
called Richmondshire, grouped round the picturesque castle of Richmond in the North Riding of Yorkshire. Other Richmond estates were along the south-east coast of Lincolnshire, in West Norfolk round their town of Swaffham, in southern Cambridgeshire, and in the neighbourhood of their castle of Hastings, in Sussex.

The Earls of Oxford were the most insignificant of English earls. An Essex family, first brought into importance, as Mr. Round has shown us, by their kinship with the Mandevilles, the Veres had practically nothing to do with Oxfordshire, the shire from which they took their title. Their only considerable estate was in North Essex. Castle Hedingham was their chief seat, and round it their chief manors were grouped. An outlying stretch of their territory was placed south of the Blackwater, between Manningtree and Harwich.

I cannot now go on to other great houses, who in point of view of territory and influence were worthy to be added to the list of earls, and who were certainly more important than a weak earl like the Earl of Oxford. The great border family of Mortimer; the Mowbrays, mighty men in Yorkshire, in the Isle of Axholme, and in Leicestershire; the great Durham and North Yorkshire house of the Nevilles; the Yorkshire family of the Percies, translated to Northumberland-were only some instances of families that were steadily preparing their way to attain the dignity of earldoms. All these houses acquired the rank of earl before the fourteenth century had come to a close. The very fact that they had not obtained this rank under Edward I. tended to that curious concentration of power in the hands of a very select circle of great earls which is, as I pointed out, the special feature of the reign. Edward was tempted by this to persevere in his policy of connecting the few surviving great houses with the crown. But the same failure met his efforts as that which attended the more famous but essentially similar policy of Edward III. The family settlement of Edward III. brought about the Wars of the Roses. The family 
settlement of Edward I. explains the reign of Edward II. While Edward I.'s earls died in their beds at a good old age, the younger generation of earls who started on their career along with Edward of Carnarvon mostly met their end on the battlefield or on the scaffold. And the only effect of allying the royal blood with the hereditary local feuds of rival houses was to degrade and cheapen the royal authority. It is thus not without its significance that the struggle for the Gloucester succession brought down the throne of Edward II. 